\title{
TINJAUAN HUKUM TERHADAP \\ KEGAWATDARURATAN MEDIS YANG TIMBUL AKIBAT KEGAGALAN USAHA ABORSI
}

\author{
Elfan Winoto \\ Program Studi Magister Hukum Fakultas Hukum \\ Universitas Hang Tuah Surabaya, Indonesia \\ Email :elfanwinoto91@gmail.com
}

\begin{abstract}
Abstrak
Aborsi adalah penyebab tertinggi kelima angka kematian ibu. Aborsi dibenarkan atau legal disebut abortus provokatus medisinalis dan yang kriminal atau ilegal disebut abortus provokatus kriminalis. Hukum Indonesia melarang melakukan aborsi kecuali indikasi kegawatdaruratan medis dan akibat pemerkosaan.Tujuan penelitian, mengetahui akibat hukum seseorang yang gagalmelakukan aborsi dan perlindungan hukum dokter yang merawatnya. Jenis penelitian,yuridis normatif dengan pendekatan konseptual dan perundangan. Hasil penelitian, kegawatdaruratan medis setelah kegagalan usaha aborsi, pelaku danyang membantu diancam Pasal 53 KUHP, termasuk percobaan melakukan kejahatan. Jika aborsi menyebabkan bayi meninggal diancam Pasal 346, 347, 348, dan 349 KUHP. Tindak pidana dapat dilakukan sendiri atau bersama, sehingga dapat dihukum sebagai pelaku atau pembantu kejahatan. Perlindungan hukum dokter yang merawat pasien gawat darurat akibat kegagalan usaha aborsi, tidak dapat dihukum jika sesuai standar profesional dan standar operasional prosedur menyelamatkan ibu dan atau janin sesuai UU No 29 Tahun 2004pasal 50 dan UU No 36 Tahun 2014 Pasal 57. Permenkes No 290 / MENKES / PER / III / 2008 Pasal 4, tindakan medis darurat tidak memerlukan izin. Hal ini tidak berlaku untuk aborsi karena dengan indikasi darurat medis, dilakukan setelah konseling sebelum dan sesudah tindakan aborsi sesuai UU No 36 Tahun 2009 Pasal 75.
\end{abstract}

Kata kunci : Kegagalan; Aborsi; Kehamilan; Kegawatdaruratan Medis; Dokter.

\begin{abstract}
Abortion is the fifth highest cause of maternal mortality. Justified or legal abortion is called medical provocate abortion and criminal or illegal is called provocate criminal criminal abortion. Indonesian law prohibits having an abortion unless indicative of medical emergencies and the result of rape. This type of research, normative juridical with a conceptual approach and legislation. The results of the study, medical emergencies after the abortion attempt failed, the perpetrators and those who helped were threatened by Article 53 of the Criminal Code, including attempted crime. If an abortion causes the baby to die under threat of Article 346, 347, 348 and 349 of the Criminal Code. Crimes can be carried out alone or together, so that they can be punished as perpetrators or crime assistants. Legal protection for doctors who treat emergency patients due to the failure of the abortion business cannot be punished if it is in accordance with professional standards and operational standard procedures for saving mothers and / or fetuses in accordance with Law No. 29/2004 on Article 50 and Law No. 36 of 2014 Article 57. Permenkes No. 290 / MENKES / PER / III / 2008 Article 4, emergency medical measures do not require a permit. This does not apply to abortion because with indications of medical emergencies, carried out after counseling before and after the act of abortion in accordance with Law No. 36 of 2009 Article 75.
\end{abstract}

Keywords: Failure; Abortion; Pregnancy; Medical Emergencies; Doctor. 


\section{A. PENDAHULUAN}

Status legal aborsi merupakan indikator penting kemampuan perempuan untuk menikmati hak reproduksi mereka. Batasan hukum tentang aborsi sering menyebabkan tingginya tingkat aborsi ilegal dan tidak aman, dan ada kaitan antara aborsi yang tidak aman dan angka kematian ibu. Undang-undang Kesehatan (selanjutnya disingkat UUK) serta Peraturan Pemerintah (selanjutnya disingkat PP) juga memperbolehkan aborsi dengan alasan adanya indikasi kedaruratan medis yang dideteksi sejak usia dini kehamilan, baik yang mengancam nyawa ibu dan/atau janin yang lahir cacat sehingga sulit hidup diluar kandungan.

Upaya pencegahan terjadinya aborsi yang tidak aman sangat penting bila Indonesia ingin mencapai tujuan ke lima dari Millennium Development Goal (selanjutnya disingkat MDGs) untuk menurunkan Angka Kematian Ibu (selanjutnya disingkat AKI) menjadi 102 per 100.000 kelahiran hidup pada tahun $2015 .^{1}$

Menurut Departemen Kesehatan Republik Indonesia tahun 2004, penyebab tingginya angka kematian ibu dan bayi akibat komplikasi kehamilan dan persalinan adalah perdarahan $45,2 \%$, hipertensi (preeklamsia dan eklamsia) $12,9 \%$, aborsi $11,1 \%$, sepsis post partum $9,6 \%$, persalinan lama $6,5 \%$, anemia $1,6 \%$, dan penyebab kematian tidak langsung $14,1 \%$. Di Indonesia, aborsi menjadi penyebab tertinggi kelima kematian ibu setelah perdarahan $28 \%$, eklamsia $24 \%$, infeksi $11 \%$, dan komplikasi pada masa puerpureum $8 \%{ }^{2}$

Diperkirakan sekitar 4,7\% - 13,2\% kematian ibu dikaitkan dengan aborsi yang tidak aman dan setiap tahunnya sekitar 7 juta wanita diantar ke rumah sakit di negara berkembang akibat aborsi yang tidak aman. ${ }^{3}$

Aborsi secara medis adalah keluarnya hasil konsepsi sebelum janin mampu hidup di luar rahim yaitu sebelum 20 minggu dan atau berat janin kurang dari 500 gram. Dalam pendekatan medis, aborsi terdiri dari dua macam yaitu aborsi spontan (abortus spontaneous) dan aborsi yang disengaja (abortus provocatus). Abortus provocatus ialah penghentian atau pengeluaran hasil kehamilan dari rahim sebelum waktunya. Sejauh ini, persoalan aborsi pada umumnya dianggap oleh sebagian masyarakat sebagai tindak pidana. Namun dalam hukum positif Indonesia tindakan abortus pada sejumlah kasus tertentu dibenarkan apabila merupakan abortus provocatus medicinalis. Sedangkan abortus yang digeneralisasi menjadi suatu tindak pidana lebih dikenal sebagai abortus provocatus criminalis. ${ }^{4}$

Aborsi dan kehamilan yang tidak diinginkan merupakan permasalahan yang terabaikan dibanyak negara berkembang, termasuk Indonesia. Sebagai tenaga kesehatan yang menyatu dengan masyarakat, bidan sering didatangi oleh perempuan dengan masalah ini. Penyebab terjadinya aborsi dan kehamilan yang tidak diinginkan antara lain karena ketidaktahuan perihal sistem reproduksinya, korban pemerkosaan, pengetahuan kurang tentang kesehatan reproduksi, hingga kegagalan kontrasepsi. ${ }^{5}$

Di Indonesia, aborsi diatur oleh beberapa jenis peraturan perundang-undangan. Sebelumnya tindakan aborsi diatur pada Pasal 15 UU Nomor 23 Tahun 1992 tentang Kesehatan yang kemudian mengalami penggantian dengan UU Nomor 36 Tahun 2009 tentang Kesehatan, yaitu pada pasal $75 .{ }^{6}$

${ }^{1}$ Ferry Efendi dan Makhfudli.(2009). Keperawatan Kesehatan Komunitas Teori dan Praktik dalam Keperawatan, Salemba Medika, Jakarta, hlm. 205.

${ }^{2}$ Ns. Wagiyo dan Putrono.(2016).Asuhan Keperawatan Antenatal, Intranatal Bayi Baru Lahir Fisiologis dan Patologis, ANDI, Yogyakarta, hlm. 133.

${ }^{3}$ Say L,et al.(2014). Global causes of maternal death: a WHO systematic analysis. Lancet Glob Healt,:e323-33.

${ }^{4}$ Kusmaryanto.(2002). Kontroversi Aborsi, PT. Gramedia Indonesia, Jakarta, hlm. 20

${ }^{5}$ Gita Farelya.(2015). Etikolegal dalam Pelayanan Kebidanan. Deepublish, Yogyakarta, hlm. 86.

${ }^{6}$ Fajlurrahman Jurdi.(2016).Teori Negara Hukum, Malang: Setara Press. 
Ketentuan dalam KUHP dilandasi suatu pemikiran bahwa anak yang masih dalam kandungan merupakan subjek hukum sehingga berhak untuk mendapatkan perlindungan hukum. Selain itu, apabila dilihat dari aspek HAM bahwa setiap orang berhak untuk hidup maupun mempertahankan hidupnya, sehingga pengguguran kandungan (aborsi) dapat dikualifikasikan sebagai tindakan yang melanggar hak asasi manusia. Dengan kata lain adanya pemikiran yang mengedepankan hak anak untuk dijaga dan dilindungi. Oleh karena itu dalam KUHP tindakan aborsi dikualifikasikan sebagai kejahatan terhadap nyawa.

Berdasarkan uraian di atas, maka dapat dirumuskan permasalahan sebagai berikut: Bagaimana akibat hukum terhadap seseorang yang gagal melakukan usaha aborsi dan menimbulkan kegawatdaruratan medis? Dan Bagaimana perlindungan hukum terhadap dokter yang merawat pasien gawat darurat medis akibat kegagalan usaha aborsi?

\section{B. METODE PENELITIAN}

Dalam penelitian ini menggunakan tipe penelitian yuridis normatif dengan pendekatan konseptual (conceptual approach) dan pendekatan perundang-undangan (statute approach).

\section{PEMBAHASAN}

\section{Pengertian Aborsi}

Kata aborsi berasal dari bahasa latin yaitu aboriri yang artinya keguguran. Aborsi didefinisikan sebagai penghentian kehamilan secara spontan atau diinduksi, sebelum bayi dapat melangsungkan hidupnya. ${ }^{7}$ The National Center for Health Statistics, The Center for Disease Control and Prevention, dan The World Health Organization, semuanya mendefinisikan aborsi sebagai penghentian kehamilan sebelum 20 minggu kehamilan atau dengan berat bayi kurang dari 500 gram.

\section{Klasifikasi Aborsi}

Klasifikasi aborsi menurut William Obstetrics, adalah:

a. Aborsi spontan

Aborsi spontan dibagi menjadi aborsi imminens, aborsi insipien, aborsi inkomplet, aborsi inkomplet, aborsi komplet, missed abortion, dan aborsi sepsis.

b. Aborsi Berulang

c. Aborsi yang diinduksi

Abortus provocatus ini dibagi 2 kelompok yaitu abortus provocatus medisinalis dan abortus provocatus kriminalis, disebut medisinalis bila didasarkan pada pertimbangan dokter untuk menyelamatkan ibu.

Ditinjau dari aspek hukum, abortus provocatus dapat digolongkan menjadi dua jenis, yaitu:

(1)Abortus provocatus legal, yaitu aborsi yang dilakukan menurut syarat dan cara-cara yang dibenarkan oleh Undang-Undang. Alasan yang mendasar adalah untuk menyelamatkan jiwa ibu hamil;

(2)Abortus provocatus ilegal, yaitu aborsi yang di dalamnya mengandung unsur kejahatan dan tidak memenuhi syarat dan cara-cara yang dibenarkan oleh Undang-Undang. ${ }^{8}$

\footnotetext{
${ }^{7}$ F. Gary Cunningham et.al,(2014)Williams Obstetrics, Mc Graw-Hill Education,hlm.350.

${ }^{8}$ Ratna Winahyu Lestari Dewi dan Suhandi,(2011), “Aborsi Bagi Korban Pemerkosaan Dalam Perspektif Etika Profesi Kedokteran, Hukum Islam Dan Peraturan Perundang-Undangan”, Jurnal Kajian Masalah Hukum Dan Pembangunan, Perspektif, Publish Or Perish Volume XVI, Nomor II,hlm. 137.
} 


\section{Akibat Hukum Terhadap Tindak Pidana Aborsi di Indoneia}

Aborsi adalah suatu perbuatan yang mengganggu moral dan religius masyarakat Indonesia sebab jika dikaji dari sudut pandang budaya, sosial, ataupun agama tidak dibenarkan tindakan pengguguran kandungan.

Menurut Lawrence Meir Friedman berhasil atau tidaknya penegakan hukum bergantung pada tiga unsur dalam sistem hukum, yakni substansi (substance culture), struktur (structure culture), dan kultur hukum (legal culture). ${ }^{9}$

Peraturan yang berhubungan dengan usaha aborsi di Indonesia diatur dalam beberapa peraturan perundang-undangan, yaitu :

1. Kitab Undang-Undang Hukum Pidana Pasal 53, 299, 346, 347, 348 dan 349.

Dalam Pasal 299 KUHP adalah diberitahukan atau ditimbulkan harapan bahwa karena pengobatan itu hamilnya dapat digugurkan. Perbuatan yang diatur sebagai tindak pidana yang memiliki korelasi dengan perbuatan pengguguran kandungan lebih menitikberatkan pada perbuatan mengobati seorang wanita yang sedang hamil atau perbuatan menyuruh wanita tersebut supaya diobati dengan harapan dari pengobatan tersebut kehamilannya dapat digugurkan. ${ }^{10}$

MenurutPasal346,seorangwanitayangsengajamenggugurkankandunganataumenyuruh orang lain untuk itu diancam dengan pidana penjara paling lama empat tahun. Dalam pasal ini unsursengajaditempatkandidepanberartisemuaunsuryangadadibelakangunsursengajaharus diliputi unsur sengaja. Oleh karena itu yang dimaksud dengan "sengaja"adalah mempunyai niat atau keinginan untuk melakukan sesuatu. Wujud dengan sengaja dalam tindak pidana aborsi bisa berupa meminum obat peluruh haid dengan dosis yang tinggi, memasukkan benda tajam kedalam alat kelaminnya untuk menggugurkan kandungan. Selain itu ada unsur "menyebabkan gugur atau matinya kandungan" maksudnya janin yang berada di dalam kandungan wanita tersebut keluar sebelum waktunya akibat paksaan atau tindakan yang dilakukan dengan sengaja sehingga janin tersebut gugur atau mati. Oleh karena itu dalam Pasal ini menggugurkan kandungan berarti janin yang dipaksakan keluar dari rahim seorang ibu dalam keadaan mati.

KUHP hanya melihat pengguguran kandungan sebagai perbuatan menghilangkan nyawa, oleh sebab itu pengguguran kandungan diatur dalam Bab XIX Buku II KUHP yang mengatur tentang kejahatan terhadap nyawa dan Bab IV Buku III KUHP yang mengatur tentang pelanggaran kesusilaan. Terkait Pasal 346, 347, 348 KUHP meliputi perbuatan-perbuatan: "mengugurkan kandungan (afdrijving van de vruch atau vruch afdrijving) dan mematikan kandungan (de dood van de vrucht veroorzaken atau vrucht doden)". Di dalam KUHP tidak diberikan penjelasan mengenai pengertian kandungan, bahkan KUHP juga tidak memberikan penjelasan mengenai perbedaan istilah menggugurkan dan mematikan kandungan. Pengertian kandungan ini amat penting artinya sebagai dasar analisis Pasal 346, 347, 348 KUHP untuk menentukan kapan suatu perbuatan dapat dikatakan menggugurkan kandungan atau kapan perbuatan dikatakan mematikan kandungan.

2. Undang-Undang Nomor 36 Tahun 2009 tentang Kesehatan Pasal 75 dan pasal 76

MenurutKUHP(Pasal299,346,347,348) setiap tindakan mematikan atau menggugurkan kandungan seorang perempuan diancam pidana tanpa kecuali dan dengan alasan apapun. Seperti juga KUHP, Undang-Undang Nomor 36 Tahun 2009 tentang Kesehatan pada dasarnya melarang aborsi. Perbedaanya, menurut KUHP aborsi dilarang tanpa diberikan perkecualian termasuk abortus provokatus medisinalis, sementara UU Nomor 36 Tahun 2009 tentang

\footnotetext{
${ }^{9}$ Arfin Leonarda Sambas K.(2016).Teori-Teori Klasik \& Kontemporer, Bogor: Penerbit Ghalia Indonesia, hlm. 134.

${ }^{10} \mathrm{Ibid}$, hlm.72
} 
Kesehatanmemberikan perkecualianbahwa aborsidapatdilakukan denganalasan atau indikasi yang tecantum dalam pasal 75 ayat 2.

Apabila didasarkan pada Pasal 75 ayat 1, bahwa setiap bentuk aborsi dilarang. Prinsip tersebut sama dengan KUHP. Alasan atau indikasi aborsi menurut Pasal 75 ayat 2 adalah dasar yang menghapuskan sifat melawan hukumnya aborsi, oleh karena itu tidak dapat dipidana.

Dalam Undang-Undang Kesehatan (selanjutya disingkat UUK) tidak dijelaskan apa yang dimaksud dengan kedaruratan medis sebagai dasar untuk melakukan tindakan aborsi. Menurut penulis, seharusnya ada batasan dari pengertian kedaruratan medis itu sendiri, sebab seiring dengan kemajuan ilmu pengetahuan dan teknologi di dunia kedokteran telah banyak kondisi-kondisi kesehatan ibu dan janin yang telah dapat diatasi atau sebaliknya justru ada kondisi-kondisi kesehatan ibu dan janin yang sama sekali baru terjadi, dengan demikian penyalagunaan tindakan aborsi yanga mengatasnamakan 'kedaruratan medis' dapat diminimalisir.

Bertolak dari unsur-unsur diatas maka UUK tidak membedakan subyek pelaku aborsi apakah orang biasa ataukah juru obat, bidan atau dokter. Sistem penjatuhan pidana juga bersifat akumulasi pidana penjara dan pidana denda.

3. Peraturan Pemerintah Nomor 61 Tahun 2014 Tentang Kesehatan ReproduksiPasal 31, 32, 33, dan 35

BerbedadenganKUHPyangtidakmenyebutkanmengenaialasanpengecualianmelakukan aborsi, baik dalam PP No 61 tahun 2014 tentang Kesehatan Reproduksi dan UU No 36 Tahun 2009 tentang Kesehatan disebutkan adanya pengecualian melakukan tindakan aborsi. Pengecualian terhadap tindakan aborsi dapat dilakukan atas indikasi kedaruratan medis yang dapat mengancam nyawa dan kesehatan ibu dana atau janin. Selain itu, kehamilan akibat perkosaan juga merupakan salah satu pengecualian dimana tindakan aborsi dapat dilakukan.

Berkaitan dengan masalah ini, kesepakatan mengenai indikasi medis atau kesehatan sebetulnya belum jelas di kalangan medis sendiri. Indikasi medis yang umum digunakan adalahberdasarkankondisiklinis penderita tanpamemperhatikan faktor-faktor sosial.Indikasi medis dalam arti sempit sangat terbatas pada indikasi vital yaitu aborsi yang dilakukan untuk menyelamatkan jiwa ibu yang mengandung karena terancam bahaya maut yang tidak dapat dielakkan dengan cara apapun kecuali dengan cara menggugurkan kandungannya. Indikasi medis dalam arti luas adalah indikasi demi keselamatan atau kesehatan ibu. Indikasi medis dari tindakan aborsi ini selalu dikaitkan dengan usaha untuk memelihara kesehatan ibu dan atau janin.

Dari peraturan-peraturan yang berlaku dan analisa peraturan tersebut diatas maka akan digunakan untuk menjawab rumusan masalah dalam bab ini. Berdasarkan teori sistem hukum oleh Friedman, sistem hukum tidak dapat berjalan tanpa adanya salah satu dari ketiga unsur sistem hukum yaitu substansi, struktur, budaya hukum. Substansi hukum yang meliputi peraturan perundang-undangan yang telah diuraikan diatas harus dipatuhi oleh dokter supaya tercipta keadilan, ketertiban dan kemanfaatan. Dokter yang mengangani pasien yang berusaha mengarborsi kandungannya juga harus patuh dengan hukum, dan kepatuhan itu dipraktikkan yaitu dengan cara menyelamatkan pasien dan janin pasien tersebut.

Struktur hukum yang meliputi aparat penegak hukum turut menentukan bisa atau tidaknya hukum itu dilaksanakan dengan baik. Oleh karena itu agar hukum dapat berjalan atau tegak dibutuhkan aparat penegak hukum yang kredibilitas, kompeten, dan independen.

Perlindungan Hukum Bagi Dokter

1. Undang-Undang Nomor 29 Tahun 2004 tentang Praktik KedokteranPasal 50 dan Pasal 51

2. Undang-Undang Nomor 36 Tahun 2014 tentang Tenaga Kesehatan Pasal 57 dan Pasal 75

3. Undang-Undang Nomor 44 Tahun 2009 Tentang Rumah SakitPasal 29 
Berdasarkan peraturan perundang-undangan yang berlaku di Indonesia, maka dokter berhak mendapatkan perlindungan hukum selama dokter menjalankan sesuai standar profesi dan standar operasional prosedur, khususnya dalam penelitian ini adalah kondisi kegawatdaruratan medis yang timbul akibat pasien gagal melakukan usaha aborsi.

Jika pasien yang gagal melakukan usaha aborsi dan timbul kegawatdaruratan medis dibawa ke rumah sakit maka pasien akan mendapatkan pertolongan awal oleh dokter umum jaga UGD. Dalam menjalankan profesinya dokter memiliki keterikatan terhadap ketentuan hukum. Selama perawatan di UGD apabila ibu hamil dan atau kandungan tersebut meninggal maka dokter yang merawat tersebut memiliki tanggung jawab hukum baik secara perdata maupun pidana.

Hubungan dokter dan pasien dalam dalam perjanjian hukum perdata termasuk kategori perikatan berdasarkan daya upaya atau usaha maksimal inspanningsverbintenis). Ini berbeda dengan ikatan yang termasuk kategori perikatan yang berdasarkan hasil kerja (resultaatsverbintenis). Pasien harus mempunyai bukti-bukti kerugian akibat tidak dipenuhinya kewajiban dokter sesuai dengan standar profesi medis yang berlaku dalam suatu kontrak terapeutik.

Hubungan dokter dan pasien dalam traksaksi terapeutik (perjanjian medis) bertumpu pada dua macam hak asasi yang merupakan hak dasar manusia, yaitu hak untuk menentukan nasib sendiri (the right to self-determination) dan hak atas dasar informasi (the right to information). Hubungan hukum kontrak terapeutik oleh undang-undang diintepretasikan berbeda walaupun secara prinsip adalah sama, yaitu hubungan pasien dengan petugas tenaga medis. UU No. 36 Tahun 2009 tentang Kesehatan menyatakan bahwa para pihak dalam kontrak terapeutik adalah pasien dengan tenaga kesehatan, sedangkan dalam UU No. 29 Tahun 2004 tentang Praktik Kedokteran menyebutkan bahwa para pihak dalam kontrak terapeutik adalah pasien dan dokter atau dokter gigi. ${ }^{11}$

Dalam pelaksanaannya perjanjian terapeutik ini harus didahului oleh adanya persetujuan tindakan tenaga kesehatan atau dokter atau dokter gigi terhadap pasien yang lazim disebut informed consent. Istilah transaksi atau perjanjian terapeutik memang tidak dikenal dalam KUH Perdata, akan tetapi dalam unsur yang terkandung dalam perjanjian terapeutik juga dapat dikategorikan sebagai suatu perjanjian sebagaimana diterangkan dalam pasal $1319 \mathrm{KUH}$ Perdata, bahwa untuk semua perjanjian baik yang mempunyai suatu nama khusus, maupun yang tidak terkenal dengan suatu nama tertentu, tunduk pada peraturan umum mengenai perikatan pada umumnya. Selain itu juga dalam ketentuan umum mengenai perikatan yang bersumber pada asas kebebasan berkontrak yang diatur dalam pasal 1338 jo. pasal $1320 \mathrm{KUH}$ Perdata yaitu asas pokok dan sahnya perjanjian.

Perjanjian yang sah adalah perjanjian yang memenuhi syarat yang telah ditetapkan oleh undang-undang. Perjanjian yang sah diakui dan diberi akibat hukum atau disebut juga legally concluded contract. Menurut pasal 1320 KUH Perdata, syarat-syarat sah perjanjian adalah :

a. Adanya persetujuan kehendak antara para pihak yang telah membuat perjanjian (consensus)

b. Adanya kecakapan para pihak-pihak untuk membuat perjanjian (capacity). Ada suatu hal tertentu (object)

c. Ada suatu sebab yang halal (causa)

Syarat pertama dan kedua pasal 1320 KUH Perdata disebut syarat subjektif, karena melekat pada diri orang yang menjadi subjek perjanjian. Jika syarat ini tidak dipenuhi, perjanjian dapat dibatalkan. Tetapi jika tidak dimintakan pembatalan kepada hakim, perjanjian itu tetap mengikat para pihak yang mengadakan perjanjian, walaupun diancam pasal pembatalan sebelum melampaui waktu lima tahun pasal 1454 KUH Perdata.

\footnotetext{
${ }^{11}$ Ibid, hlm. 46
} 
Untuk syarat ketiga dan keempat pasal 1320 KUH Perdata disebut sebagai syarat objektif, karena mengenai sesuatu yang menjadi objek perjanjian. Jika syarat ini tidak dipenuhi, perjanjian batal. Pembatalan ini dapat diketahui apabila perjanjian tidak mencapai tujuan karena salah satu pihak tidak memenuhi kewajibannya. Kemudian diperkarakan ke muka hakim dan hakim menyatakan perjanjian batal karena tidak memenuhi syarat objektif.

Perjanjian terapeutik mempunyai sifat yang lebih khusus, sehingga tidak semua ketentuan dari KUH Perdata dapat diterapkan. Sesuai Permenkes RI No 290/MENKES/PER/III/2008 tentang Persetujuan Tindakan Kedokteran pada pasal 1 angka 7 menjelaskan bahwa pasien yang kompeten adalah pasien dewasa atau bukan anak menurut peraturan perundang-undangan atau telah atau pernah menikah, tidak terganggu kesadaran fisiknya, mampu berkomunikasi secara wajar, tidak mengalami kemunduran perkembangan (retardasi) mental dan tidak mengalami penyakit mental sehingga mampu membuat keputusan secara bebas. Apabila yang mendatangi dokter adalah seorang pasien yang tidak kompeten maka tentu saja dokter tidak mungkin menolaknya.

Pemberian persetujuan tindakan medis dalam keadaan gawat darurat berbeda dengan keadaan yang tidak gawat darurat. Hal tersebut diatur dalam Permenkes No 290/MENKES/ PER/III/2008 tentang Persetujuan Tindakan Medik.Pasien yang dalam keadaan gawat darurat dan membutuhkan pertolongan medis segera, tidak dibutuhkan lagi informed consent, tetapi setelah dilakukannya tindakan perlu sesegera mungkin menjelaskan kepada pasien setelah sadar dan kepada keluarga terdekat. Hal ini berbeda apabila tindakan tersebut adalah tindakan aborsi yang dilakukan dalam keadaan gawat darurat tanpa informed consent, karena bertentangan dengan UU Kesehatan dan PP tentang Kesehatan Reproduksi. Pengecualian terhadap tindakan aborsi atas indikasi kedaruratan medis ditentukan oleh tim kelayakan aborsi yang terdiri dari dua orang tenaga kesehatan yang diketuai oleh dokter yang memiliki kompetensi dan kewenangan. Tindakan aborsi hanya dapat dilakukan setelah melalui konseling pra tindakan dan pasca tindakan yang dilakukan oleh konselor yang kompeten dan berwenang.

Jika berdasarkan asas lex superior derogat legi inferior maka dalam pelaksanaan praktik aborsi terhadap kasus kegawatdaruratan medis yang timbul akibat kegagalan usaha aborsi adalah sesuai dengan UU Kesehatan dan PP tentang Kesehatan Reproduksi. Berdasarkan jenis dan hierarki peraturan perundang-undangan dalam UU No 12 Tahun 2011 tentang Pembentukan Peraturan Perundang-undangan Kedudukan UU dan PP lebih tinggi bila dibandingkan dengan Permenkes.

Selain itu juga, berdasarkan asas lex specialis derogat legi generalis maka UU Kesehatan dan PP tentang Kesehatan Reproduksi bersifat mengatur secara khusus mengenai kesehatan terutama praktik aborsi. Sedangkan Permenkes tentang Persetujuan Tindakan Kedokteran tidak menyebutkan secara khusus mengenai tindakan kedokteran apa yang boleh dilakukan demi menyelamatkan nyawa ibu dan atau janin serta mencegah kecacatan.

Syarat selanjutnya adalah adanya suatu objek tertentu (object). Pada penjelasan pasal 1333 KUH Perdata yang dimaksud dengan suatu hal tertentu adalah objek perjanjian harus tertentu setidak-tidaknya harus dapat ditentukan. Syarat yang terakhir mengenai adanya suatu sebab yang halal (causa). Dalam hubungan dokter dan pasien yang menyangkut pelayanan medik digunakan sebagai objek yang diperjanjikan. Kedua pihak menghendaki suatu yang halal, karena dengan ilmu pengetahuan yang sudah diperoleh dokter guna menolong pasien yang sakit, pasien juga berkehendak yang halal, yaitu kesembuhan kesehatannya. Sehingga syarat pada pasal $1320 \mathrm{KUH}$ Perdata sudah dapat terpenuhi.

Khususnya dalam kondisi kegawatdaruratan, pasien atau keluarga pasien memerlukan kepandaian dan keterampilan dokter untuk mengatasi masalah kesehatannya atau keluarganya, sedangkan para dokter mempunyai kepandaian dan keterampilan yang dapat diberikannya 
untuk kesembuhan pasien. Secara tidak langsung, akibat persetujuan ini akan terjadi perjanjian antara dua pihak. Kedua pihak bersetuju dan berjanji untuk melakukan sesuatu dalam bidang pengobatan atau kesehatan. Akibat persetujuan dan perjanjian ini akan terjadi perikatan antara kedua pihak yaitu dokter dan pasien.

Dalam undang-undang dijelaskan bahwa yang dimaksud dengan perikatan adalah hubungan hukum antara dua orang atau lebih, dengan pihak yang satu berhak menuntut sesuatu dari pihak yang lain, sedangkan pihak yang lain itu berkewajiban memenuhi tuntutan itu.

Dari ketentuan ini dapat dilihat bahwa dalam pelayanan kesehatan memang terjadi hubungan antara pasien atau keluarga pasien yang meminta bantuan dan dokter yang dengan keahlian dan keterampilan yang dimilikinya sanggup memenuhi bantuan yang diminta pasien atau keluarga pasien. Dalam hal ini dikatakan bahwa pihak pasien atau keluarga menuntut suatu prestasi dari dokter.

Suatu yang dapat dituntut dinamakan prestasi dan biasanya timbul akibat adanya perikatan. Menurut pasal 1234 Kitab Undang-undang Hukum Perdata "Tiap-tiap perikatan adalah untuk memberikan sesuatu, untuk berbuat sesuatu, atau untuk tidak berbuat sesuatu". Dalam ikatan dokter dengan pasien, prestasi yang utama adalah "melakukan sesuatu perbuatan" meskipun dalam hal tertentu prestasi dapat "tidak melakukan sesuatu".

Dalam bidang medis, para dokter dan masyarakat menyadari bahwa tidak mungkin dokter menjamin upaya pengobatan akan selalu berhasil sesuai yang diinginkan pasien atau keluarga. Yang dapat diberikan dokter adalah upaya maksimal berdasarkan kemampuan dan pengetahuannya untuk menolong pasien. Hasil dari usaha tersebut bukan suatu kepastian akan kesembuhan. Hal ini disebabkan oleh daya tahan tubuh pasien adalah tidak sama, tingkat keparahan penyakit pada saat pasien datang kepada dokter atau rumah sakit juga memengaruhi, serta kepekaan atau efek samping obat terhadap masing-masing pasien adalah tidak sama.

Tanggung jawab pidana seorang dokter seiring dengan semakin meningkatnya kesadaran hukum masyarakat banyak menimbulkan permasalahan, khususnya yang menyangkut dengan kelalaian yang dilandaskan pada teori-teori kesalahan dalam hukum pidana. Tanggung jawab pidana disini timbul jika pertama-tama dapat dibuktikan adanya kesalahan profesional, misalnya kesalahan dalam diagnosis atau kesalahan dalam cara pengobatan atau perawatan. Kesalahan atau kelalaian akan selalu berkaitan dengan sifat melawan hukumnya suatu perbuatan yang dilakukan oleh orang yang mampu bertanggung jawab.

Sehubungan dengan kemampuan bertanggung jawab dalam menentukan bahwa seseorang itu bersalah atau tidak menurut hukum, ditentukan oleh tiga faktor yaitu keadaan batin orang yang melakukan itu, maksudnya adalah bahwa pelaku menyadari atau tidak perbuatan yang dilakukan itu merupakan perbuatan yang dilarang oleh undang-undang dan adanya hubungan batin antara pelaku dan perbuatan yang dilakukan, yaitu berupa dolus (kesengajaan) atau culpa (kelalaian/kealpaan), serta tidak adanya alasan pemaaf.

Mengenai kelalaian (negligence) mencakup dua hal, yaitu karena melakukan sesuatu yang seharusnya tidak dilakukan atau karena tidak melakukan sesuatu yang seharusnya dilakukan. ${ }^{12}$

Kesalahan atau kelalaian tenaga kesehatan dapat terjadi di bidang hukum pidana, diatur dalam pasal 263,267, 294 ayat 2, 299, 304, 322, 344, 347, 348, 349, 351, 359, 360, 361, dan 531 KUHP.

Perbedaan penting antara tindak pidana biasa dan tindak pidana medis. Pada tindak pidana biasa, yang terutama diperhatikan adalah akibatnya, sedangkan pada tindak pidana medis adalah penyebabnya. Walaupun berakibat fatal, tetapi jika tidak ada unsur kelalaian atau kesalahan, dokter tidak dapat dipersalahkan.

${ }^{12}$ Endang Kusuma Astuti,(2009)Transaksi Terapeutik dalam Upaya Pelayanan Medis di Rumah Sakit, Citra Aditya Bakti,hlm. 281

40 Elfan Winoto | Tinjauan Hukum Terhadap Kegawatdaruratan .... 
Aborsi yang dilakukan tanpa indikasi medis merupakan salah satu contoh dari criminal malpractice yang berupa kesengajaan. Mengenai abortus tanpa indikasi medis walaupun kenyataan di lapangan banyak terjadi, tidak banyak kasus yang sampai ke pengadilan. ${ }^{13}$

Dalam literatur hukum kedokteran dengan sistem hukum Anglo Saxon dikatakan bahwa seorng dokter baru dapat dipersalahkan apabila memenuhi syarat 4D, yaitu : duty (kewajiban), derelictions of that duty (penyimpangan kewajiban), damage (kerugian), dan direct causal relationship (berkaitan langsung).

Dokter dalam menjalankan praktik kedokteran wajib untuk membuat rekam medis dan apabila akan dilakukan tindakan kedokteran maka diperlukan adanya persetujuan tindakan kedokteran yang disebut dengan informed consent. Menurut Permenkes No 269/MENKES/ PER/III/2008 tentang Rekam Medis, rekam medis adalah berkas yang berisikan catatan dan dokumen tentang identitas pasien, pemeriksaan, pengobatan, tindakan dan pelayanan lain yang telah diberikan kepada pasien. Sedangkan menurut Permenkes No 290/MENKES/PER/ III/2008 tentang Persetujuan Tindakan Kedokteran, persetujuan tindakan kedokteran adalah persetujuan yang diberikan oleh pasien atau keluarga terdekat setelah mendapat penjelasan secara lengkap mengenai tindakan kedokteran atau kedokteran gigi yang akan dilakukan terhadap pasien. Kegunaan rekam medis dan informed consent adalah pada saat diperlukan pembuktian.

Jika sudah dapat dibuktikan bahwa dokter tersebut telah merawat pasien dengan usaha maksimal untuk menyelamatkan nyawa pasien, maka dokter tersebut dapat secara medis dan hukum dikatakan bahwa dokter tersebut melakukan pekerjaannya dan tidak melanggar hukum walaupun bayi tersebut meninggal dan dapat dibuktikan bahwa dokter tidak melanggar standar operasional prosedur dan tidak melakukan malpraktek.

\section{KESIMPULAN}

Apabila aborsi tersebut tidak menyebabkan berakhirnya kehamilan maka diancam dengan KUHP pasal 53 ayat 1 karena termasuk dalam percobaan melakukan kejahatan.Meskipun hanya memberitahukan atau menimbulkan pengharapan bahwa kandungan tersebut dapat digugurkan seseorang dapat diancam dengan pasal 299 KUHP.Apabila tindakan aborsi tersebut tersebut dilakukan oleh ibu hamil itu sendiri dan mengakibatkan bayi meninggal maka ibu tersebut diancam dengan pasal 346 KUHP. Sedangkan bila tindakan aborsi dilakukan oleh orang lain dan mengakibatkan ibu dan bayi tersebut meninggal maka diancam dengan pasal 347 atau 348 KUHP. Bila orang lain tersebut adalah dokter, bidan, atau juru obat maka berdasarkan pasal 349 KUHP ancaman pidananya dapat ditambah sepertiga dan dapat dicabut hal untuk melakukan pencariannya. Bagi seseorang yang melakukan, menyuruh melakukan, turut serta, memberi atau menjanjikan sesuatu dengan menyalahgunakan kekuasaan atau martabat, dengan kekerasan, ancaman atau penyesatan, atau dengan memberi kesempatan, sarana atau keterangan, sengaja menganjurkan orang lain supaya melakukan perbuatan diancam dengan KUHP pasal 55 sebagai pelaku pidana.Sedangkan bagi seseorang yang dengan sengaja memberi bantuan, kesempatan, sarana, dan keterangan untuk melakukan kejahatan diancam dengan KUHP pasal 56 dan dipidana sebagai pembantu suatu kejahatan. Ancaman pidana bagi pelaku aborsi juga tercantum dalam UU Kesehatan pasal 194, dimana dapat menjerat siapa saja yang dengan sengaja melakukan aborsi.Perlindungan hukum terhadap dokter yang merawat pasien gawat darurat medis akibat kegagalan usaha aborsi AdalahDokter dan rumah sakit memiliki kewajiban untuk melakukan pertolongan darurat dan memberikan pelayanan medis sesuai dengan UU No 36 tahun 2009 tentang Kesehatan, UU No 44 tahun 2009 tentang

\footnotetext{
${ }^{13}$ Ibid. hlm. 282
} 
Rumah Sakit, UU No 29 tahun 2004 tentang Praktik Kedokteran, dan Kode Etik Kedokteran. Dokter memiliki hak memperoleh perlindungan hukum sepanjang melaksanakan tugas sesuai dengan standar profesi dan standar operasional prosedur sesuai dengan UU No 29 Tahun 2004 Tentang Praktik Kedokteran Pasal 50 dan UU No 36 Tahun 2014 Tentang Tenaga Kesehatan Pasal 57.Meskipun menurut Permenkes No 290/Menkes/PER/III/2008 Pasal 4 dalam keadaan kegawatdaruratan medis tidak diperlukan persetujuan tindakan kedokteran, hal tersebut tidak berlaku bagi tindakan aborsi. Karena menurut UU Kesehatan perkecualian terhadap larangan aborsi yaitu indikasi kedaruratan medis hanya dapat dilakukan setelah melalui konseling dan atau penasehatan pra dan pasca tindakan oleh konselor yang kompeten dan berwenang. Selain itu, indikasi kedaruratan medis harus ditentukan melalui tim kelayakan aborsi yang terdiri dari dua orang tenaga kesehatan yang diketuai oleh dokter yang memiliki kompetensi dan wewenang.Dokter tidak dapat dipidana sebagai pelaku tindak pidana ataupun sebagai pembantu kejahatan aborsi apabila dapat dibuktikan bahwa tindakan mengakhiri kehamilan tersebut dilakukan dalam kondisi kegawatdaruratan untuk menyelamatkan nyawa ibu dan atau janin serta mencegah kecacatan setelah adanya usaha aborsi.

\section{Daftar Pustaka}

\section{Buku}

Arfin Leonarda Sambas K.(2016). Teori-Teori Klasi k\& Kontemporer, Bogor: Ghalia Indonesia.

Endang Kusuma Astuti. (2009). Transaksi Terapeutik dalam Upaya Pelayanan Medis di Rumah Sakit, Citra Aditya Bakti.

F. Gary Cunningham et.al.(2014). Williams Obstetrics, McGraw-Hill Education.

Fajlurrahman Jurdi.(2016). Teori Negara Hukum, Malang: Setara Press.

Ferry Efendi dan Makhfudli.(2009). Keperawatan Kesehatan Komunitas Teori dan Praktik dalam Keperawatan, Jakarta: Salemba Medika.

Kusmaryanto.(2002). Kontroversi Aborsi, Jakarta: PT. Gramedia Indonesia.

Gita Farelya.(2015). Etikolegal dalam Pelayanan Kebidanan, Yogyakarta: Dee publish.

Ns. Wagiyo dan Putrono.(2016). Asuhan Keperawatan Antenatal, Intranatal Bayi Baru Lahir Fisiologis dan Patologis, Yogyakarta: ANDI.

Say L,et al.(2014). Global causes of maternal death: a WHO systematic analysis. Lancet Glob Healt.

RatnaWinahyu Lestari Dewi dan Suhandi.(2011). “Aborsi Bagi Korban Pemerkosaan Dalam

Perspektif Etika Profesi Kedokteran, Hukum Islam Dan PeraturanPerundangUndangan”, Jurnal Kajian Masalah Hukum Dan Pembangunan, Perspektif, Publish Or Perish Volume XVI, Nomor II. 